\title{
Chiral Benzoins via Asymmetric Transfer Hemihydrogenation of Benzils: The Detail that Matters
}

Lorena De Luca and Antonio Mezzetti*

Dept. of Chemistry and Applied Biosciences, ETH Zurich, 8093 Zürich, Switzerland

E-Mail: mezzetti@inorg.chem.ethz.ch

\section{Supporting Information}

Table of Contents

General

$(R)$-2-Hydroxy-1,2-diphenylethan-1-one, $(R)-5 a$

S2

$(R)$-2-Hydroxy-1,2-bis(4-methoxyphenyl)ethan-1-one, $(R)-5 \mathrm{~b}$

S4

$(R)$-1,2-Bis(4-fluorophenyl)-2-hydroxyethan-1-one, $(R)-5 \mathrm{c}$

S6

$(R)$-2-Hydroxy-1,2-bis(3-methoxyphenyl)ethan-1-one, $(R)-5 d$

S8

$(R)$-1,2-Bis(3-fluorophenyl)-2-hydroxyethan-1-one, $(R)-5 \mathbf{e}$

S10

$(R)$-1,2-Bis(2-fluorophenyl)-2-hydroxyethan-1-one, $(R)-5 f$

S11

$(R)-1,2-B i s(2-c h l o r o p h e n y l)-2-h y d r o x y e t h a n-1-o n e,(R)-5 \mathbf{g}$

S13

Reaction of cis- $\beta-\left[\mathrm{FeBr}\left(\mathrm{CNCEt}_{3}\right)(1) \mathrm{BF}_{4}(7)\right.$ with $\mathrm{NaO}^{\prime} \mathrm{Pr}$.

S14

References

S17 


\section{General}

Reactions with air- or moisture-sensitive materials were carried out under an argon atmosphere using Schlenk techniques or in a glove box under argon. 2Propanol was distilled over $\mathrm{CaH}_{2}$ and stored over molecular sieves (4 $\AA$ ) for at leat three days. ${ }^{1} \mathrm{H},{ }^{13} \mathrm{C}$, and ${ }^{31} \mathrm{P}$ NMR spectra were recorded on Bruker Avance DPX 300 $\left({ }^{1} \mathrm{H}, 300.1 ;{ }^{19} \mathrm{~F}\left\{{ }^{1} \mathrm{H}\right\}, 282 ;{ }^{31} \mathrm{P}\left\{{ }^{1} \mathrm{H}\right\}, 121.5\right)$ or $500\left({ }^{1} \mathrm{H}, 500.2 ;{ }^{13} \mathrm{C}\left\{{ }^{1} \mathrm{H}\right\}\right.$, 125.8; $\left.{ }^{31} \mathrm{P}\left\{{ }^{1} \mathrm{H}\right\}, 202.5\right)$. Trace Analysis. Instrument used: Element $\mathrm{XR}$, Thermo Fisher, Germany, including "Jet" cones and nitrogen addition. As a sample introduction system was used DSN, Nu plasma, United Kingdom. Calibration: An external calibration including $\mathrm{Ca}, \mathrm{Si}$, and $\mathrm{Al}$ in 2-propanol was applied. Data processing: Ca was measured using method of sp-mode (sample time $0.001 \mathrm{~s}$ ). $\mathrm{Si}$ and $\mathrm{Al}$ standards and samples were acquired using sample time of $0.01 \mathrm{~s}$. Each sample/calibrant was measured for 3 times. Thin layer chromatography was performed on Merck silica gel 60 F254 glass plates and visualized with UV fluorescence at $254 \mathrm{~nm}$ or stained in potassium permanganate solutions. Automated flash column chromatography was performed on a CombiFlash ${ }^{\circledR}$ Rf+Lumen Automated Flash Chromatography System with UV/Vis detection using RediSep Rf prepacked columns. Complex [FeH(CNCEt 3$)\left(R_{\mathrm{P}}, R_{\mathrm{P}}, R_{\mathrm{C}}, R_{\mathrm{C}}\right)$ 1)]BF $\mathrm{B}_{\mathrm{h}}$ was prepared following the literature procedure. ${ }^{1}$

$(R)-2-H y d r o x y-1,2-d i p h e n y l e t h a n-1-o n e,(R)-5 a$

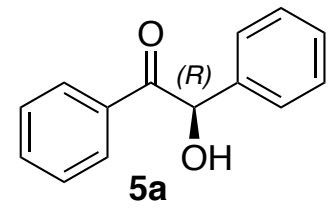

Table S1. Product distribution (determined by ${ }^{1} \mathrm{H}$ NMR spectroscopy) of the ATH of 4 a with hydride 3 as catalyst.

$\begin{array}{cccccc}\text { Entry } & t(\min ) & \mathbf{4 a}(\%) & \mathbf{5 a}(\%) & \mathbf{e e}^{\mathbf{a}}(\%) & \mathbf{6 a}(\%) \\ 1 & 15 & 51 & 48 & 94 & 1 \\ 2 & 30 & 20 & 76 & 95 & 4 \\ 3 & 45 & 7 & 83 & 98 & 10 \\ 4 & 60 & 4 & 83 & >99 & 13 \\ 5 & 75 & 2 & 82 & >99 & 16 \\ 6 & 90 & 2 & 78 & >99 & 19\end{array}$

${ }^{a}$ Enantiomeric excess of $\mathbf{5 a}$. 
Figure S1. ${ }^{1} \mathrm{H}$ NMR spectrum $\left(300 \mathrm{MHz}, \mathrm{CDCl}_{3}, 298 \mathrm{~K}\right)$ of the ATH of 4 a with 3 as catalyst (reaction time: $45 \mathrm{~min}$ ).

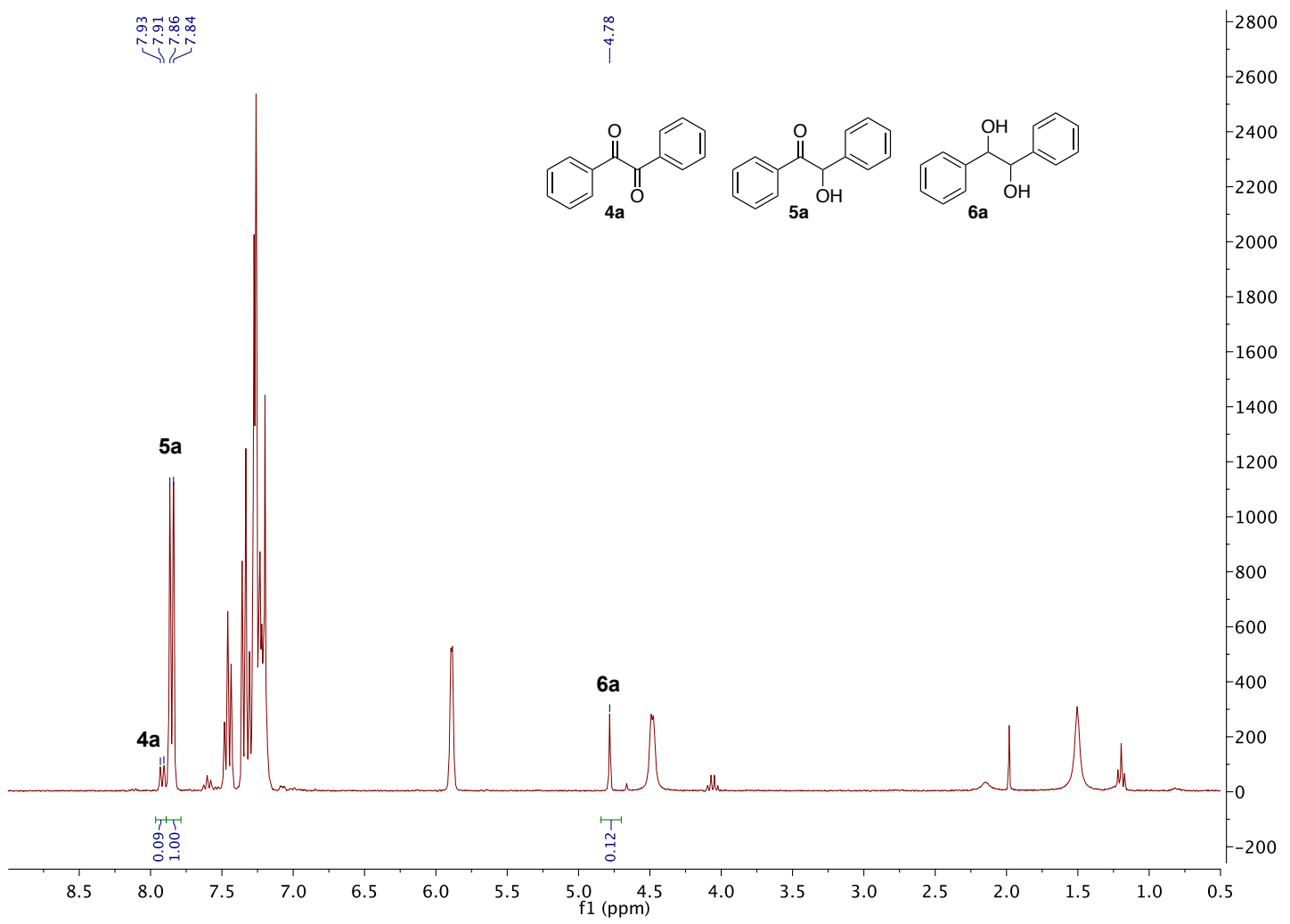

Figure S2. HPLC trace of enantioenriched ( $R$ )-5a after column chromatography (top) and of rac-5a (bottom).
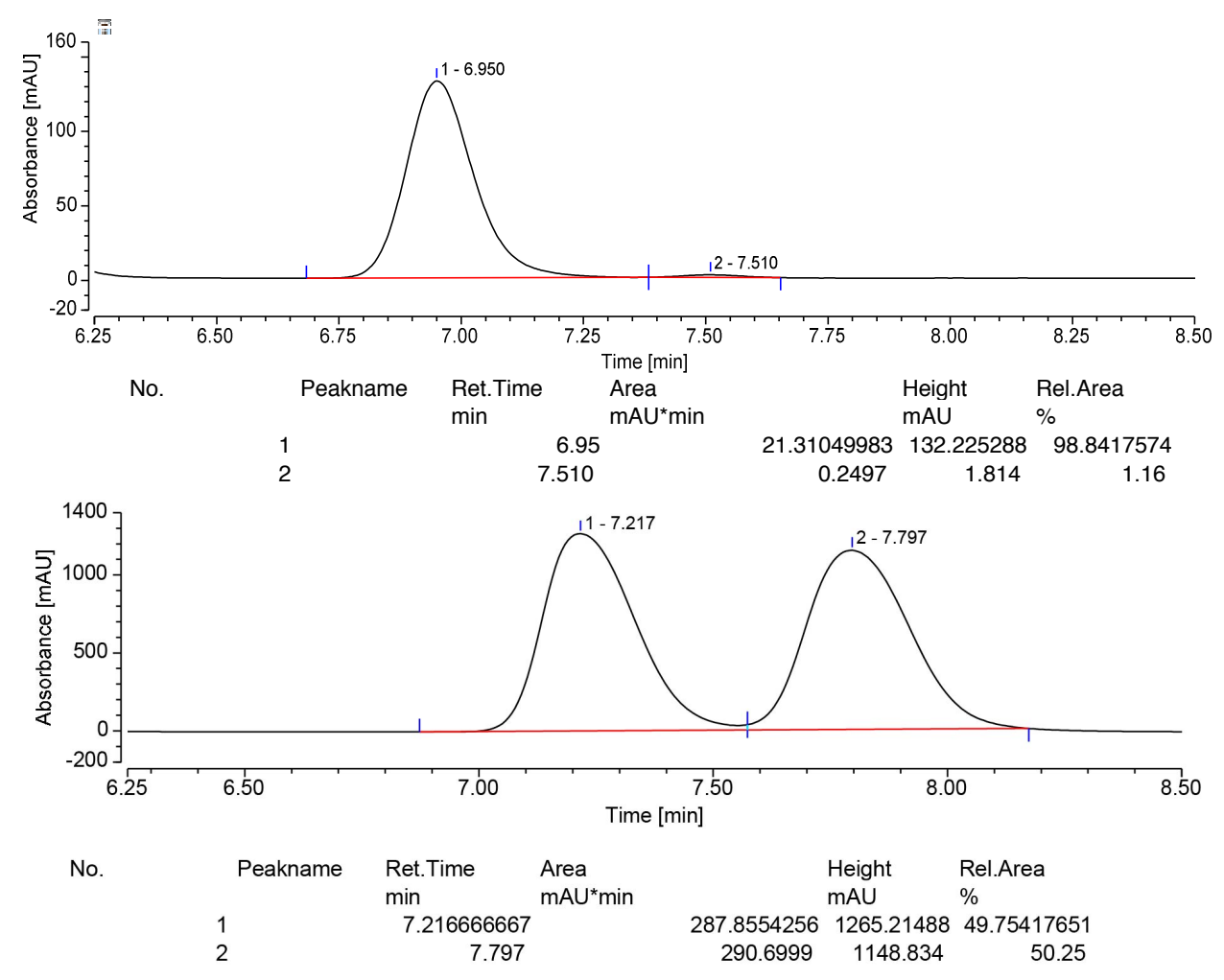
(R)-2-Hydroxy-1,2-bis(4-methoxyphenyl)ethan1-one, $(R)-5 b$

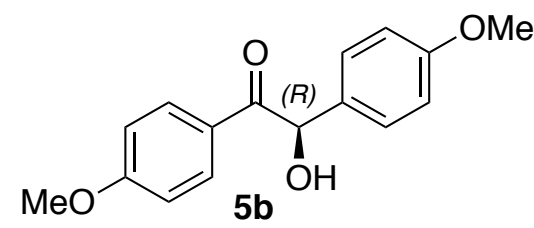

Table S2. Product distribution (determined by ${ }^{1} \mathrm{H}$ NMR spectroscopy) of the ATH of $\mathbf{4 b}$ with $\mathbf{3}$ as catalyst.

$\begin{array}{ccccc}\text { Entry } & \mathrm{t}(\mathbf{m i n}) & \mathbf{4 b}(\%) & \mathbf{5 b}(\%) & \mathbf{6 b}(\%) \\ 1 & 15 & 34 & 61 & 5 \\ 2 & 30 & 17 & 76 & 7 \\ 3 & 45 & 9 & 82 & 9 \\ 4 & 60 & 5 & 83 & 12 \\ 5 & 75 & 4 & 83 & 13 \\ 6 & 90 & 2 & 83 & 15 \\ 7 & 120 & 1 & 81 & 18\end{array}$

Figure S3. ${ }^{1} \mathrm{H}$ NMR spectrum $\left(300 \mathrm{MHz}, \mathrm{CDCl}_{3}, 298 \mathrm{~K}\right)$ of the ATH of $\mathbf{4 b}$ with $\mathbf{3}$ as catalyst (reaction time: $45 \mathrm{~min}$ ).

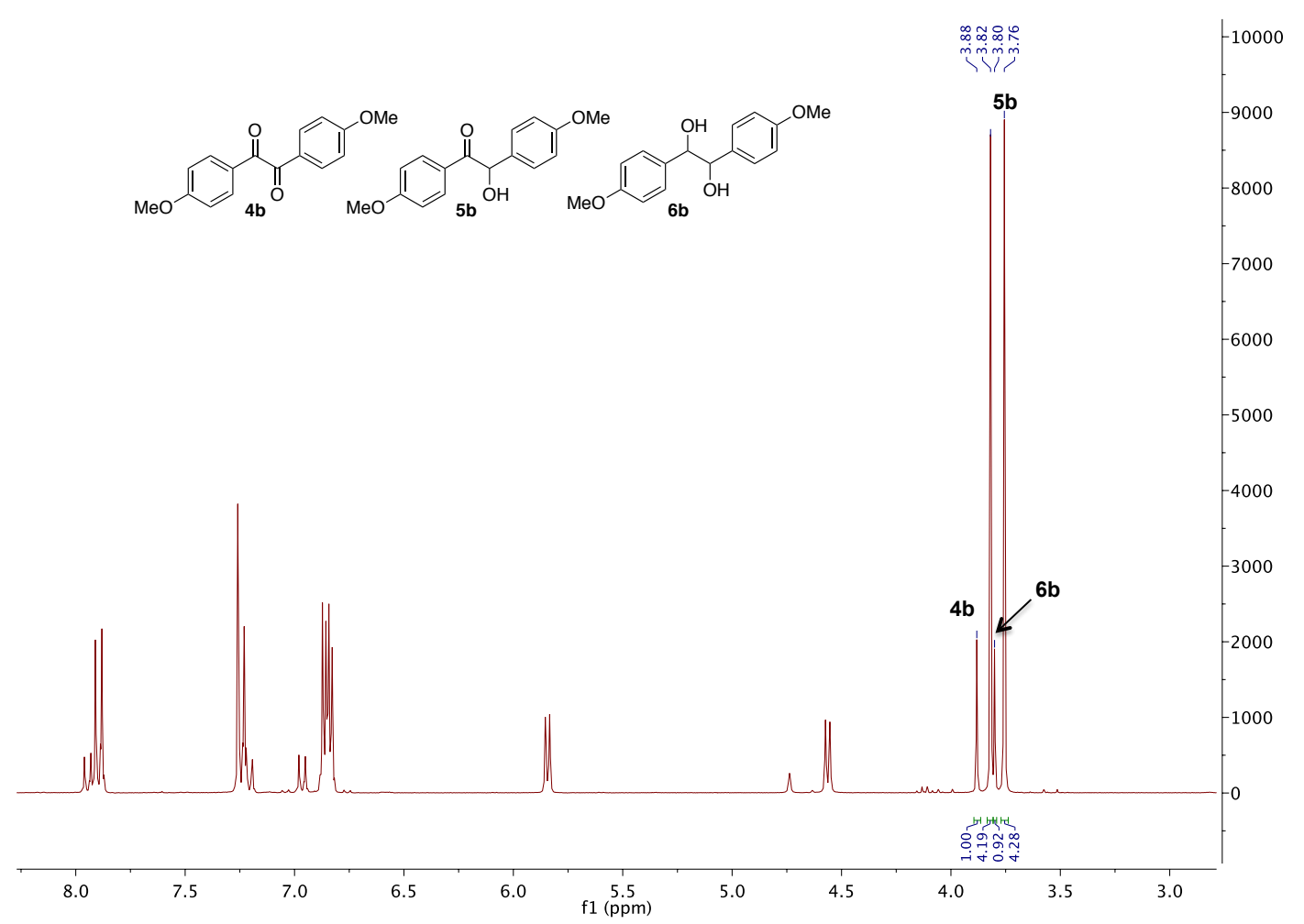


Figure S4. HPLC trace of enantioenriched $(R)-5 \mathbf{b}$ after column chromatography (top) and of commercial rac-5b (bottom).
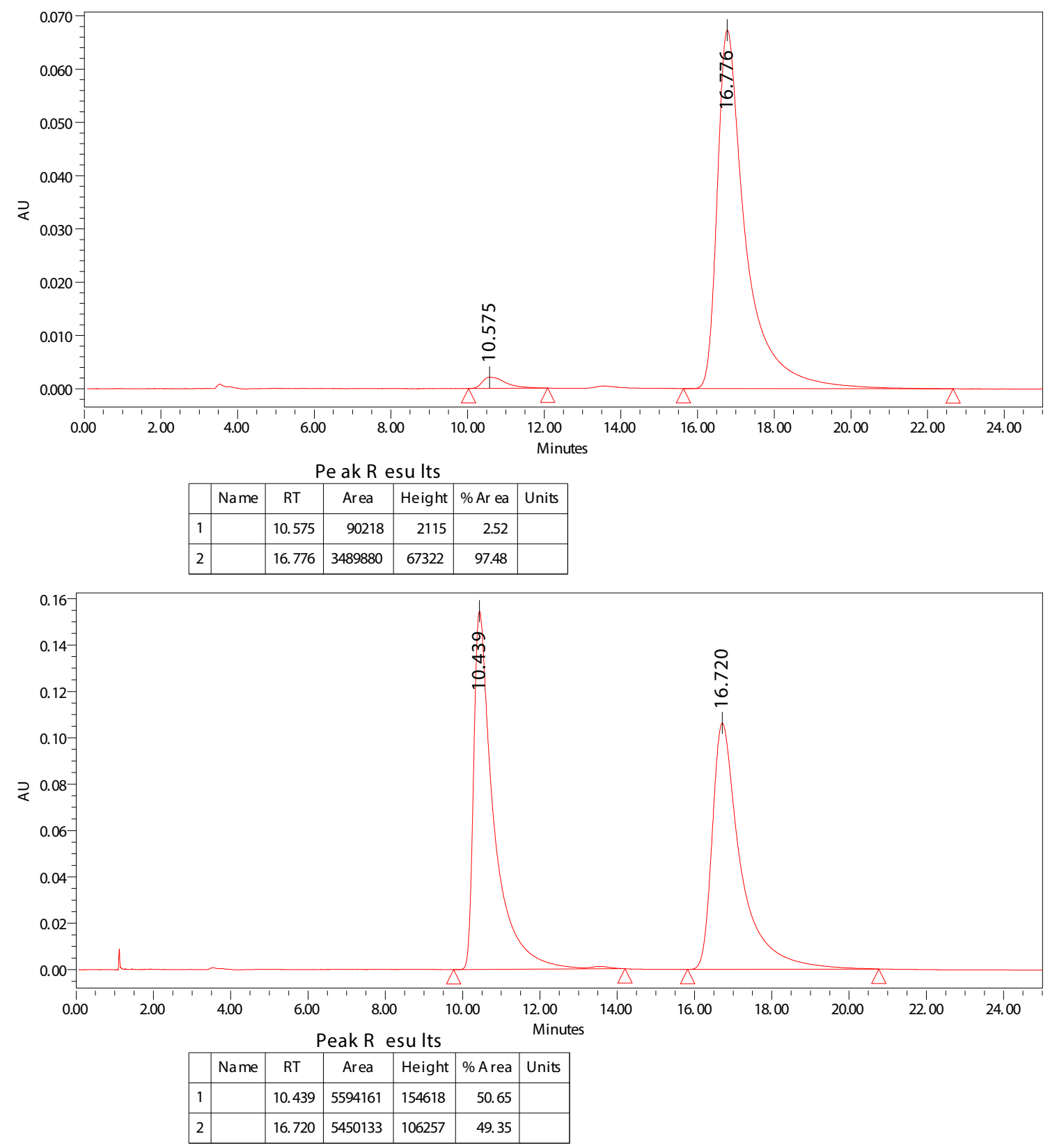
$(R)$-1,2-Bis(4-fluorophenyl)-2-hydroxyethan-1-one, $(R)-5 \mathrm{c}$

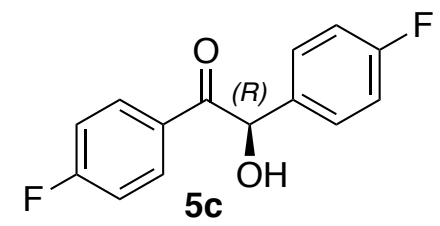

Table S3. Product distribution (determined by ${ }^{19} \mathrm{~F}\left\{{ }^{1} \mathrm{H}\right\}$ NMR spectroscopy) of the ATH of $4 c$ with 3 as catalyst.

$\begin{array}{ccccc}\text { Entry } & \mathrm{t}(\mathrm{min}) & \mathbf{4 c}(\%) & \mathbf{5 c}(\%) & \mathbf{6 c}(\%) \\ 1 & 15 & 44 & 55 & 1 \\ 2 & 30 & 19 & 75 & 6 \\ 3 & 45 & 9 & 81 & 10 \\ 4 & 60 & 3 & 83 & 14 \\ 5 & 75 & 1 & 82 & 17 \\ 6 & 90 & 1 & 80 & 19 \\ 7 & 120 & 1 & 76 & 23\end{array}$

Figure S5. ${ }^{19} \mathrm{~F}\left\{{ }^{1} \mathrm{H}\right\}$ NMR spectrum $\left(282 \mathrm{MHz}, \mathrm{CDCl}_{3}, 298 \mathrm{~K}\right)$ of the ATH of $4 \mathrm{c}$ with 3 as catalyst (reaction time: $45 \mathrm{~min}$ ).

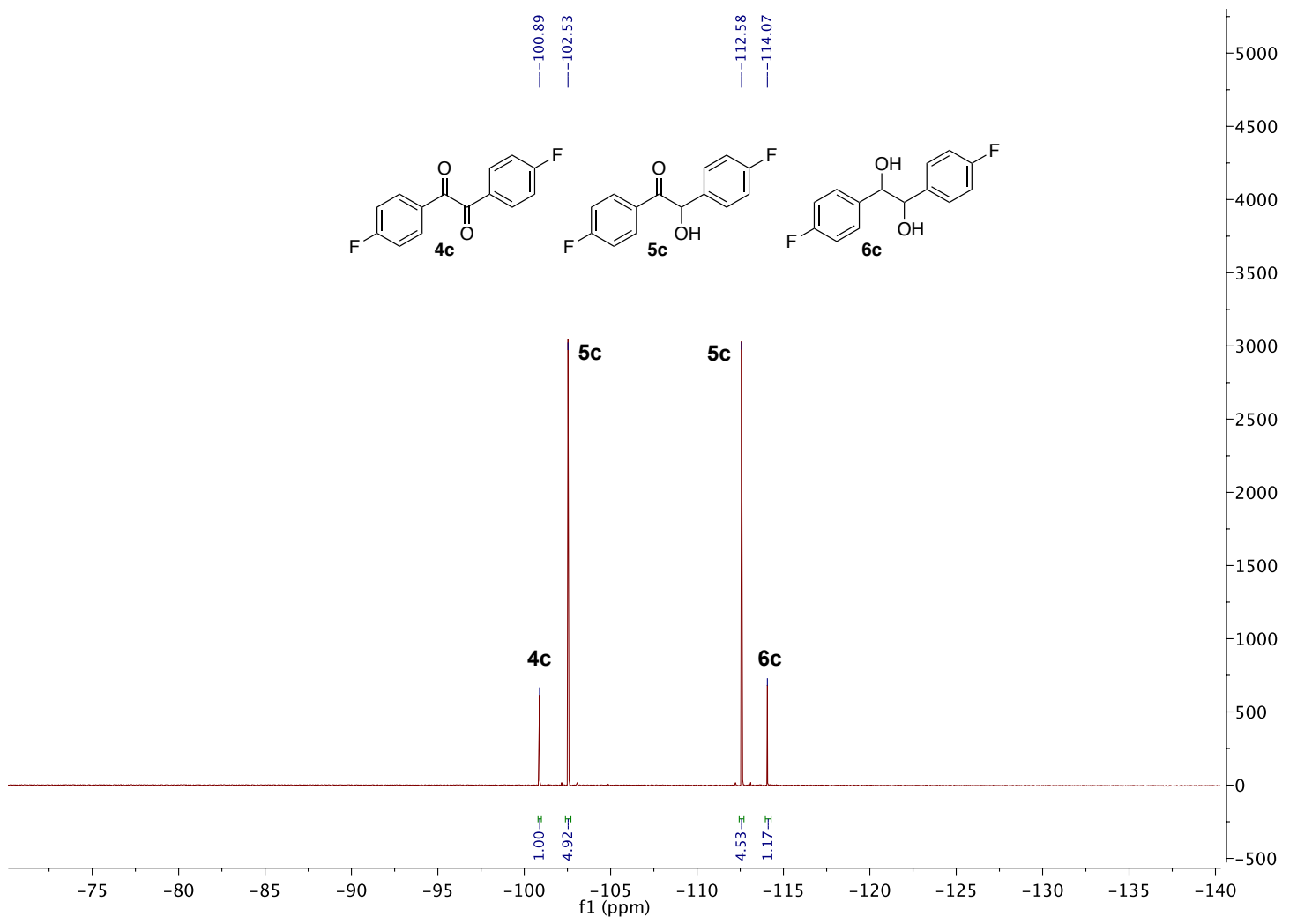


Figure S6. HPLC trace of enantioenriched ( $R$ )-5c after column chromatography (top) and rac-5c (bottom).

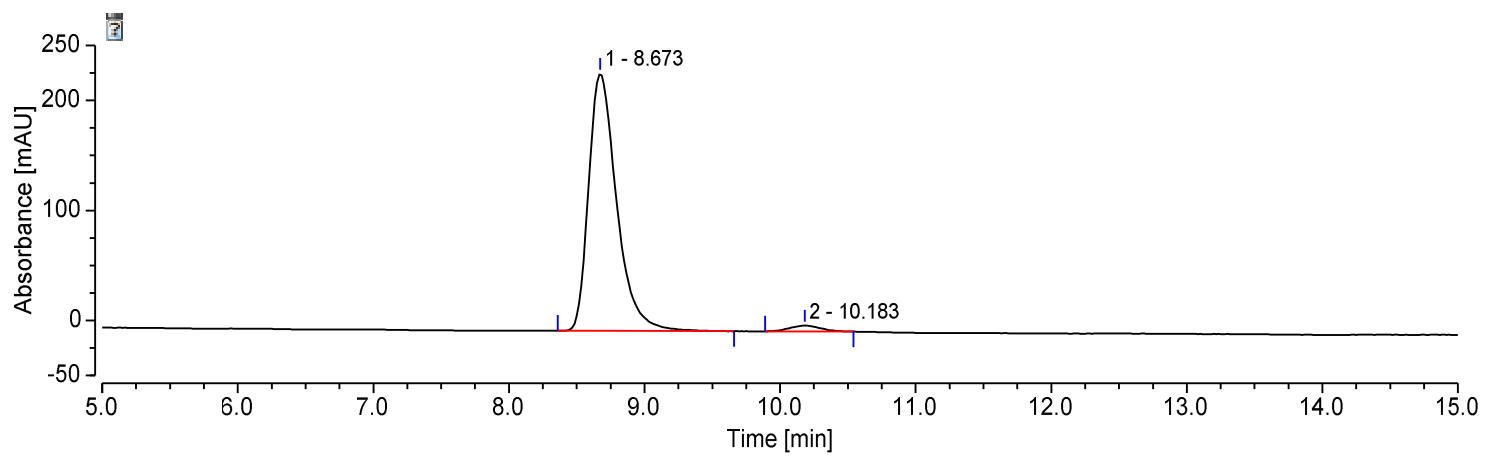

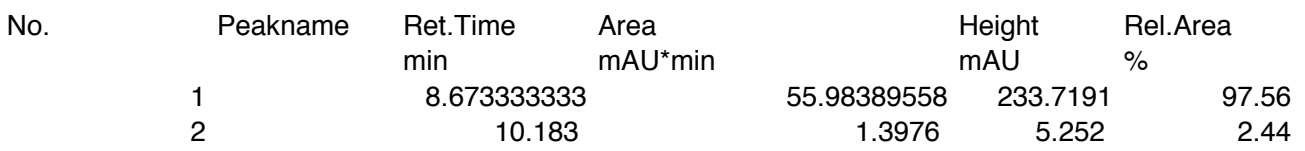

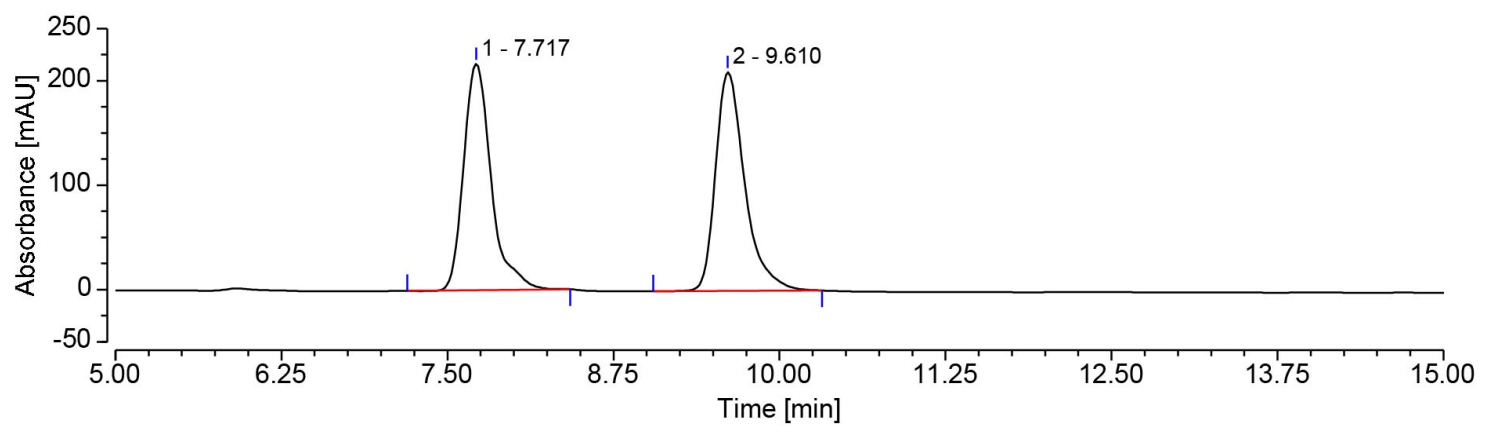

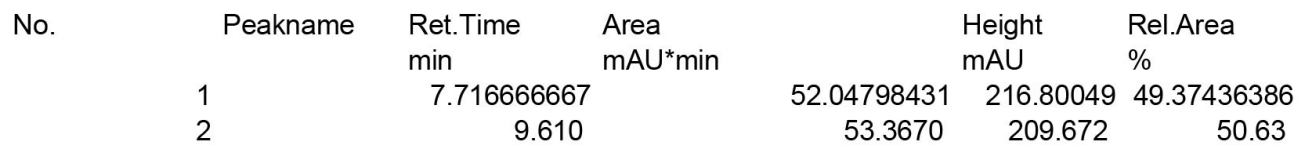


(R)-2-Hydroxy-1,2-bis(3-methoxyphenyl)ethan-1-one, $(R)$-5d

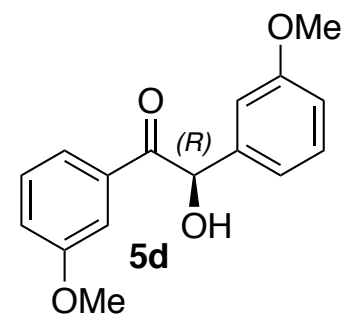

Table S4. Product distribution (determined by ${ }^{1} \mathrm{H}$ NMR spectroscopy) of the ATH of $\mathbf{4 d}$ with $\mathbf{3}$ as catalyst.

$\begin{array}{lllll}\text { Entry } & \mathrm{t}(\mathrm{min}) & \mathbf{4 d}(\%) & \mathbf{5 d}(\%) & \mathbf{6 d}(\%) \\ 1 & 15 & 45 & 53 & 2 \\ 2 & 30 & 25 & 71 & 4 \\ 3 & 45 & 13 & 81 & 6 \\ 4 & 60 & 6 & 86 & 8 \\ 5 & 75 & 3 & 86 & 12 \\ 6 & 90 & 2 & 82 & 16 \\ 7 & 120 & 2 & 78 & 20\end{array}$

Figure S7. ${ }^{1} \mathrm{H}$ NMR spectrum $\left(300 \mathrm{MHz}, \mathrm{CDCl}_{3}, 298 \mathrm{~K}\right)$ of the ATH of $\mathbf{4 d}$ with $\mathbf{3}$ as catalyst (reaction time: $45 \mathrm{~min}$ ).
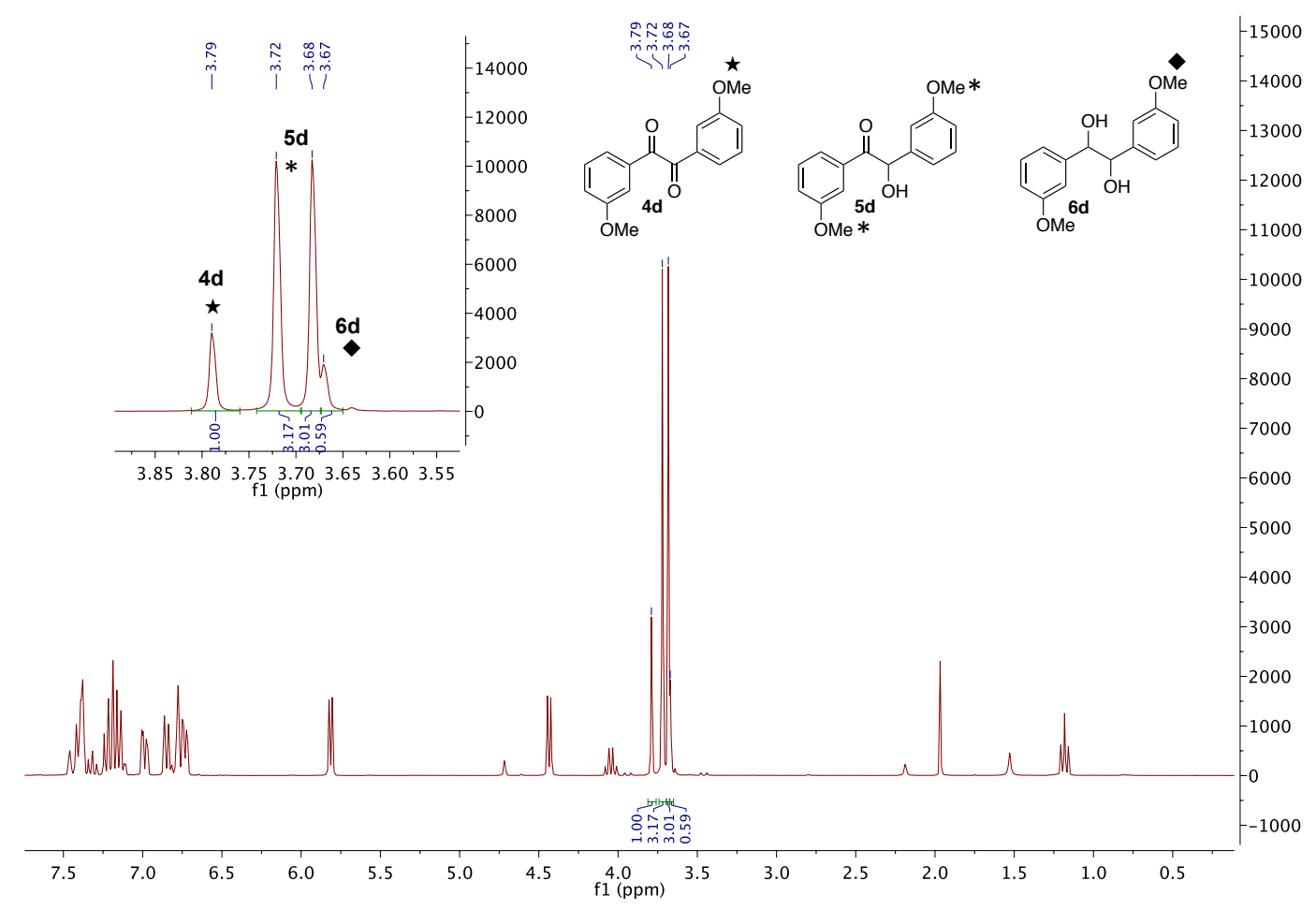
Figure S8. HPLC trace of enantioenriched ( $R$ )-5d after column chromatography (top) and of rac-5d (bottom).
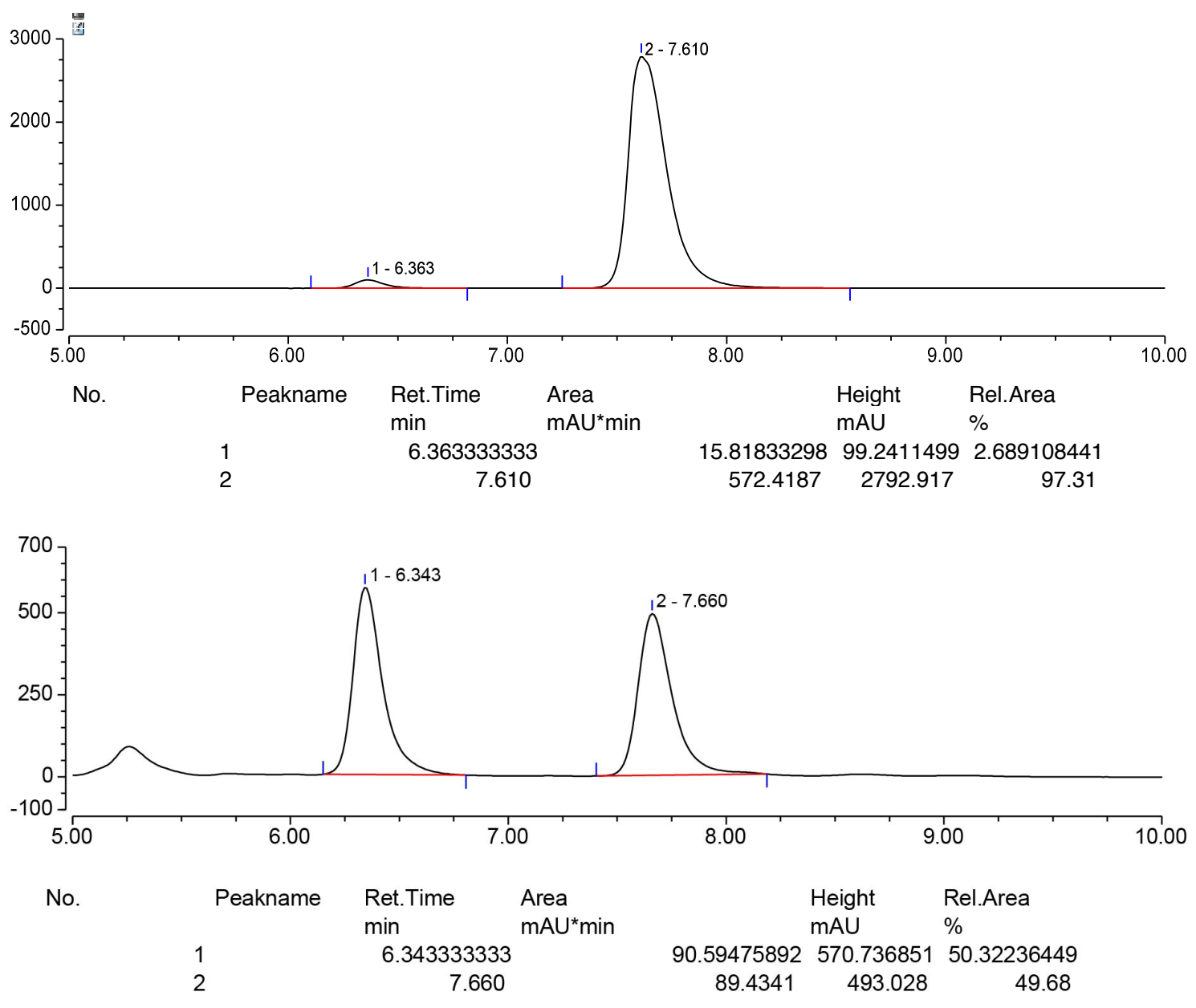
$(R)$-1,2-Bis(3-fluorophenyl)-2-hydroxyethan-1-one, $(R)$-5e

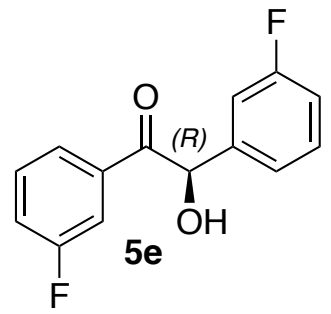

Table S5. Product distribution (determined by ${ }^{19} \mathrm{~F}\left\{{ }^{1} \mathrm{H}\right\}$ NMR spectroscopy) of the ATH of $4 \mathbf{e}$ with $\mathbf{3}$ as catalyst.

$\begin{array}{lllll}\text { Entry } & \mathrm{t} & \mathbf{4 e} & \mathbf{5 e} & \mathbf{6 e} \\ & (\min ) & (\%) & (\%) & (\%) \\ 1 & 15 & 61 & 38 & 1 \\ 2 & 30 & 40 & 56 & 4 \\ 3 & 45 & 28 & 65 & 7 \\ 4 & 60 & 19 & 70 & 11 \\ 5 & 75 & 11 & 72 & 17 \\ 6 & 90 & 6 & 70 & 24 \\ 7 & 120 & 3 & 59 & 38\end{array}$

Figure S9. ${ }^{19} \mathrm{~F}\left\{{ }^{1} \mathrm{H}\right\} \mathrm{NMR}$ spectrum $\left(282 \mathrm{MHz}, \mathrm{CDCl}_{3}, 298 \mathrm{~K}\right)$ of the ATH of $4 \mathrm{e}$ with 3 as catalyst at $60 \mathrm{~min}$ of reaction time.

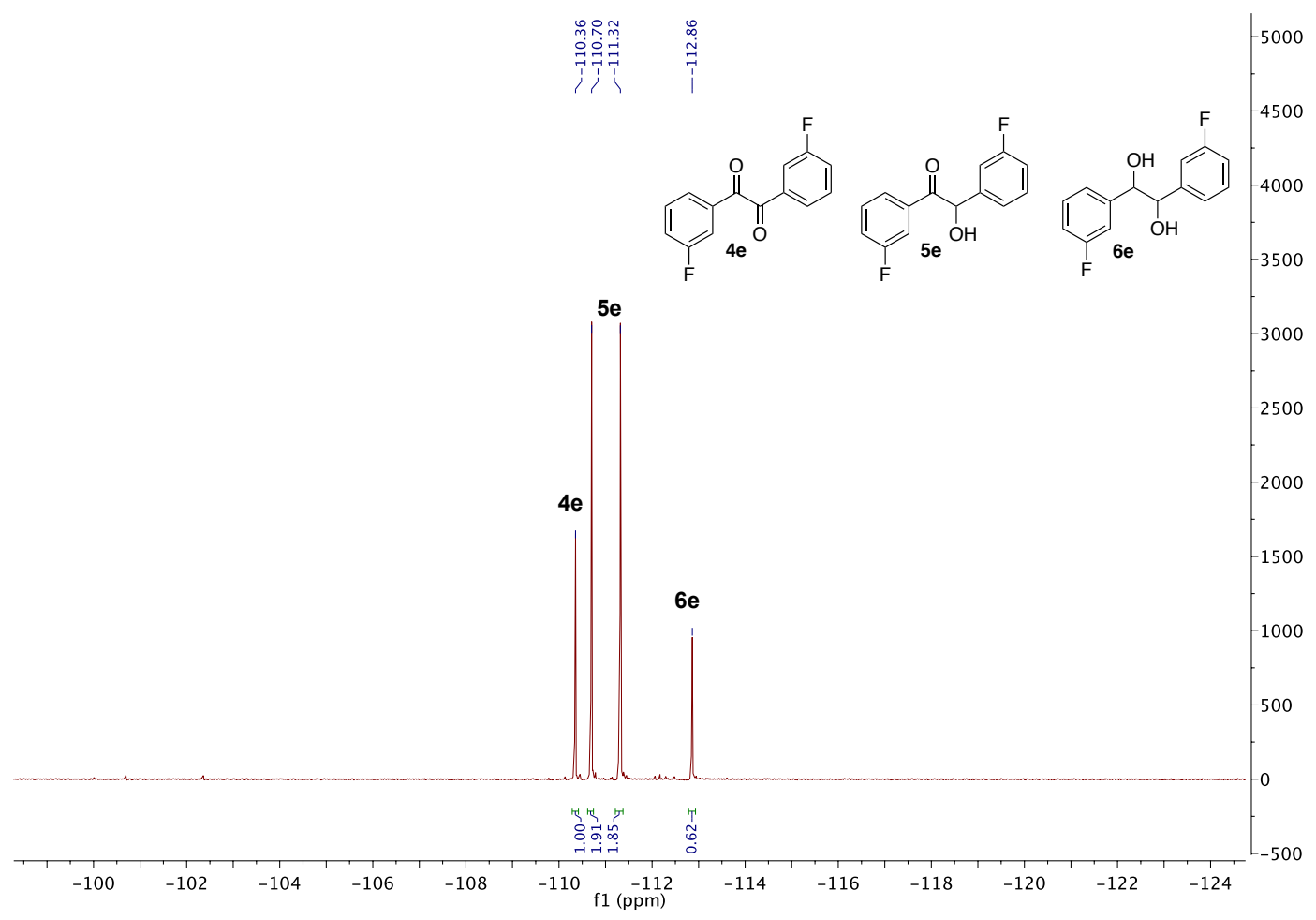


Figure S10. HPLC trace of enantioenriched $(R)-5 \mathrm{e}$ (obtained by general procedure $\mathbf{A}$ with $\mathbf{3}$ ) after column chromatography (top) and of rac-5e (bottom).
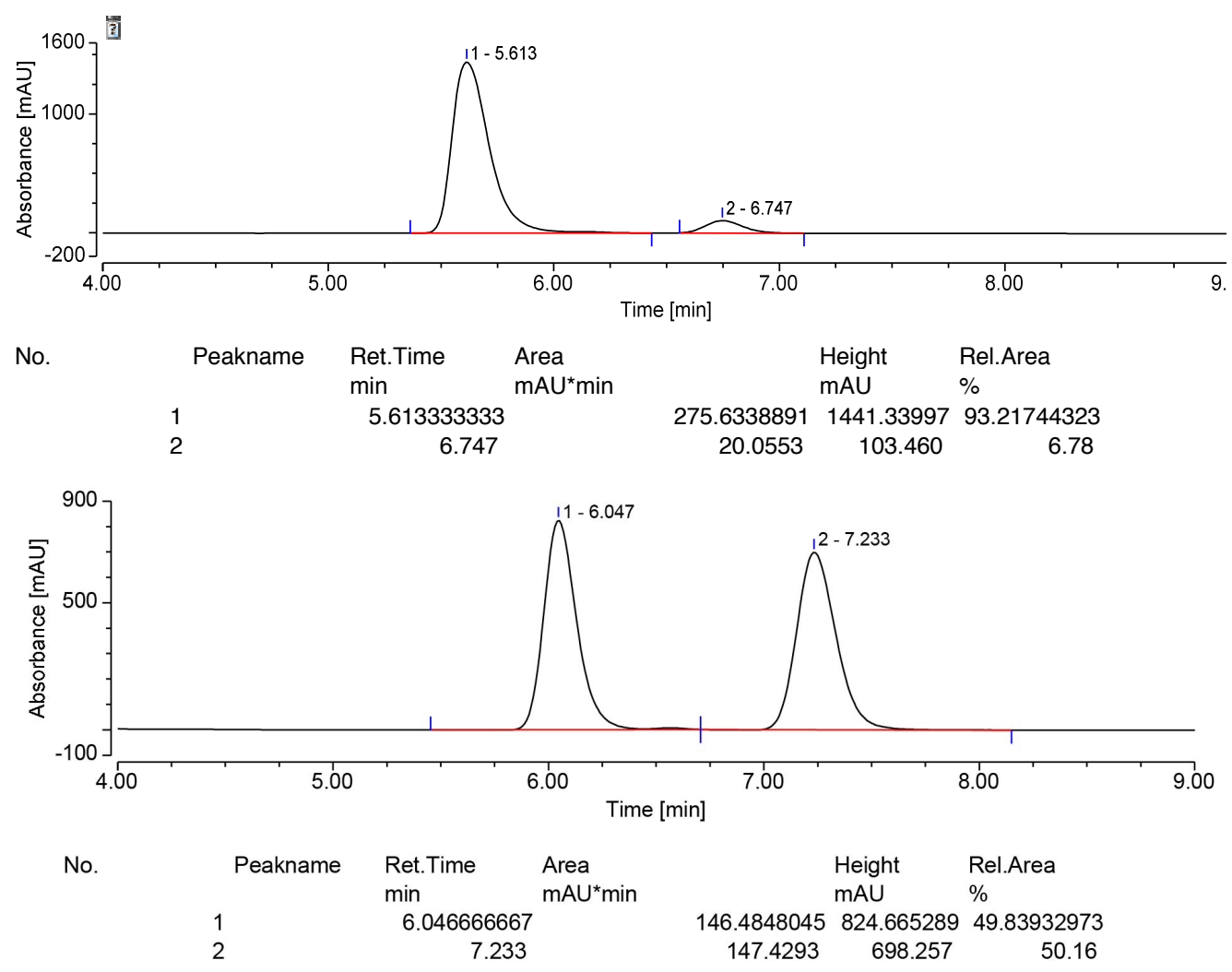

$(R)$-1,2-Bis(2-fluorophenyl)-2-hydroxyethan-1-one, $(R)-5 f$<smiles>O=C(c1ccccc1F)[C@H](O)c1ccccc1F</smiles>

Table S6. Product distribution (determined by ${ }^{19} \mathrm{~F}\left\{{ }^{1} \mathrm{H}\right\}$ NMR spectroscopy) of the ATH of $\mathbf{4} f$ with $\mathbf{3}$ as catalyst.

$\begin{array}{lllll}\text { Entry } & \mathrm{t}(\mathrm{min}) & \mathbf{4 f}(\%) & \mathbf{5 f}(\%) & \mathbf{6 f}(\%) \\ 1 & 15 & 60 & 37 & 2 \\ 2 & 30 & 49 & 46 & 5 \\ 3 & 45 & 42 & 51 & 6 \\ 4 & 60 & 37 & 55 & 8 \\ 5 & 75 & 31 & 58 & 11 \\ 6 & 90 & 31 & 56 & 13 \\ 7 & 120 & 23 & 59 & 18\end{array}$


Figure S11. ${ }^{19} \mathrm{~F}\left\{{ }^{1} \mathrm{H}\right\}$ NMR spectrum $\left(282 \mathrm{MHz}, \mathrm{CDCl}_{3}, 298 \mathrm{~K}\right)$ of the ATH of $\mathbf{4 f}$ with 3 as catalyst at 60 min of reaction time.

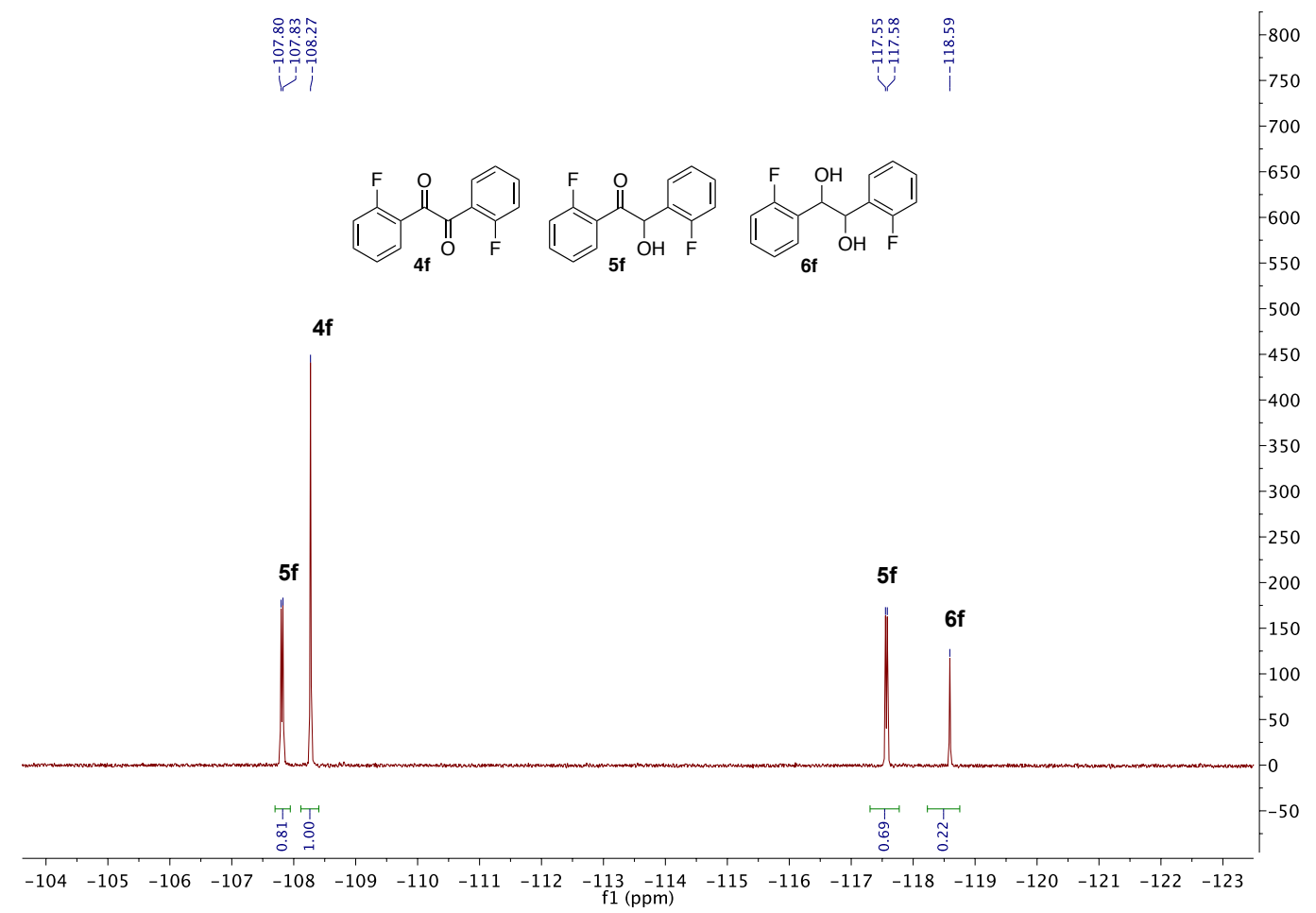

Figure S12. HPLC trace of enantioenriched $(R)$ - after column chromatography of $\mathbf{5 f}$ (top) and of rac-5f.

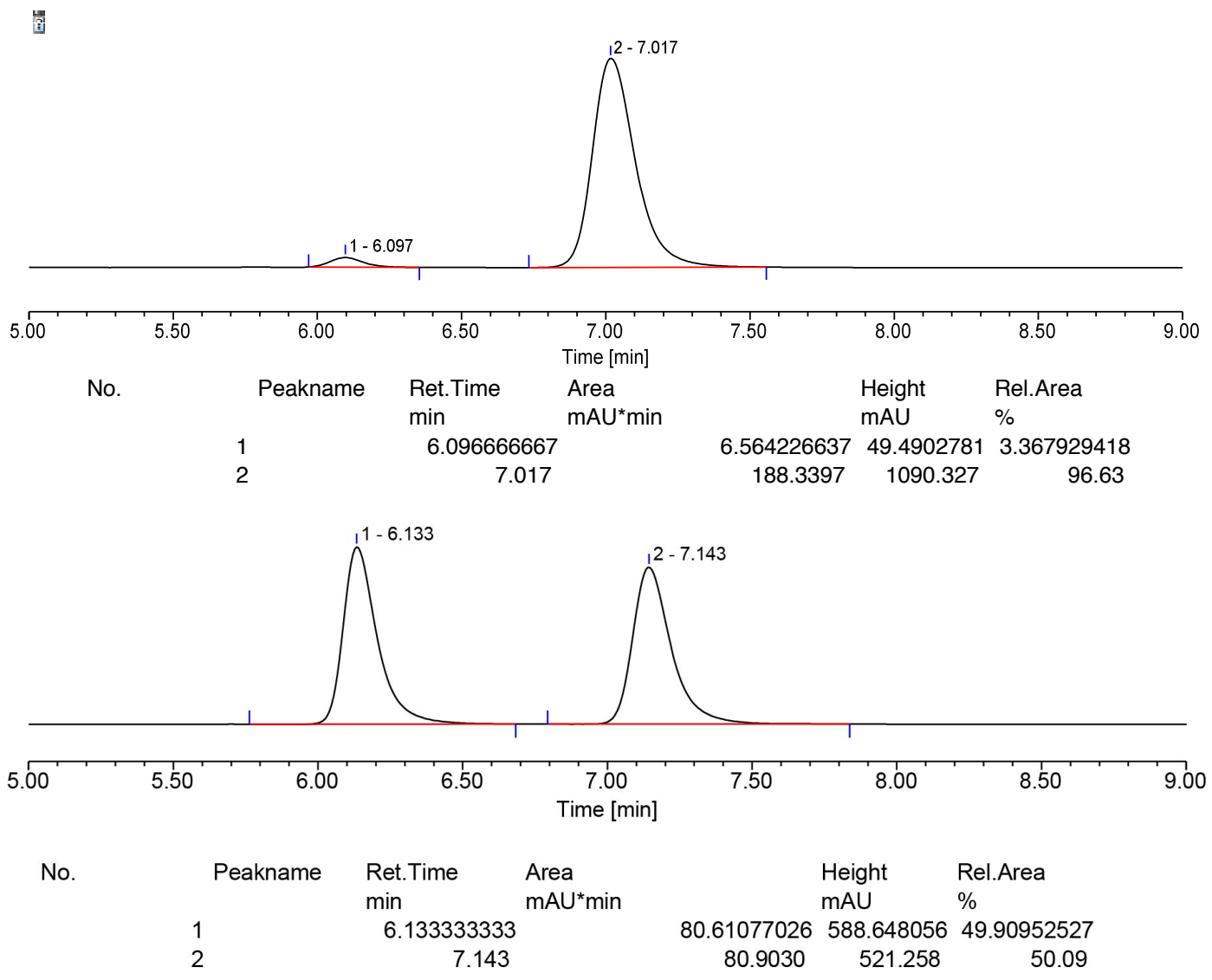


(R)-1,2-Bis(2-chlorophenyl)-2-hydroxyethan-1-one, $(R)-5 \mathrm{~g}$<smiles>O=C(c1ccccc1Cl)[C@H](O)c1ccccc1Cl</smiles>

Table S7. Product distribution (determined by ${ }^{19} \mathrm{~F}\left\{{ }^{1} \mathrm{H}\right\}$ NMR spectroscopy) of the ATH of $\mathbf{4} \mathbf{g}$ with $\mathbf{3}$ as catalyst.

$\begin{array}{lllll}\text { Entry } & \mathrm{t}(\mathrm{min}) & \mathbf{4 g}(\%) & \mathbf{5 g}(\%) & \mathbf{6 g}(\%) \\ 1 & 15 & 38 & 57 & 5 \\ 2 & 30 & 26 & 66 & 8 \\ 3 & 45 & 20 & 67 & 13 \\ 4 & 60 & 16 & 66 & 18 \\ 5 & 75 & 14 & 64 & 22 \\ 6 & 90 & 11 & 61 & 28 \\ 7 & 120 & 9 & 55 & 36\end{array}$

Figure S13. ${ }^{19} \mathrm{~F}\left\{{ }^{1} \mathrm{H}\right\}$ NMR spectrum $\left(282 \mathrm{MHz}, \mathrm{CDCl}_{3}, 298 \mathrm{~K}\right)$ of the ATH of $\mathbf{4 g}$ with 3 as catalyst at 60 min of reaction time.

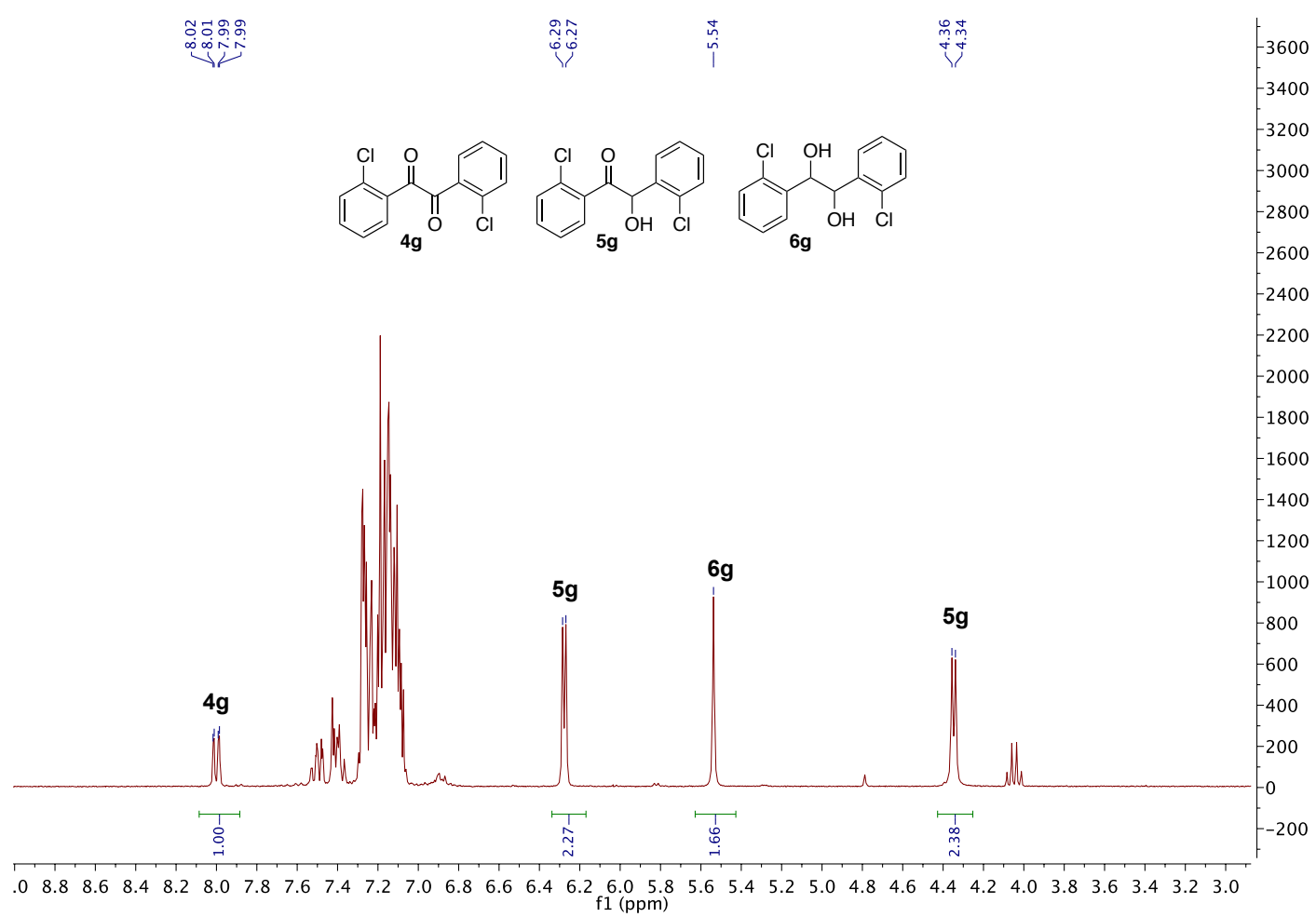


Figure S14. HPLC trace of enantioenriched $(R)-\mathbf{5 g}$ (obtained by general procedure $\mathbf{A}$ with $\mathbf{3}$ ) after column chromatography (top) and of rac-5g (bottom).

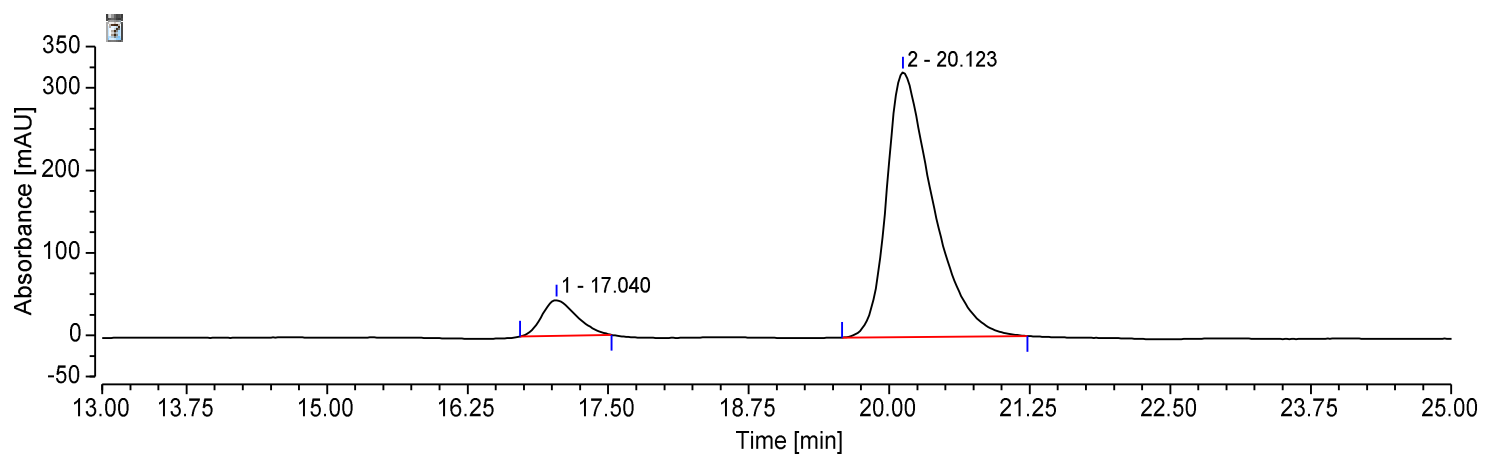

No

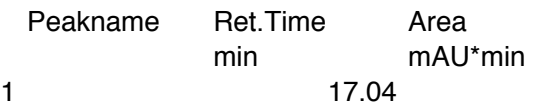

20.123
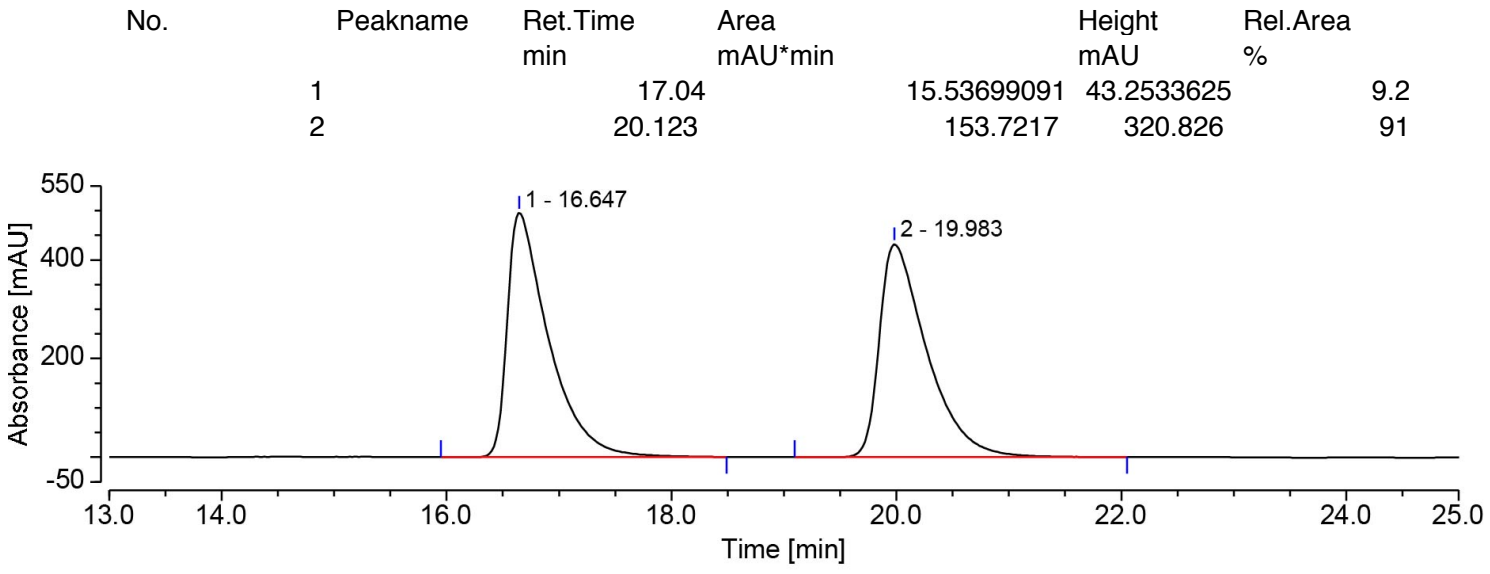

No.
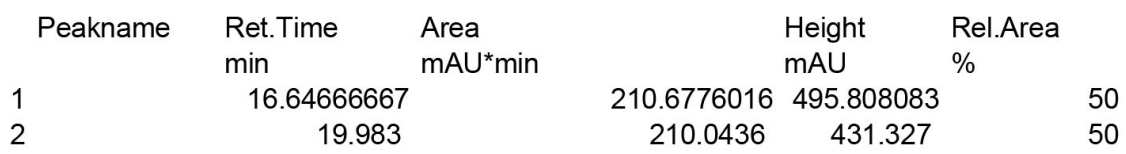

Reaction of cis- $\beta-\left[\mathrm{FeBr}\left(\mathrm{CNCEt}_{3}\right)(1) \mathrm{BF}_{4}(7)\right.$ with $\mathrm{NaO}^{i} \mathrm{Pr}$. Complex $7(9.2 \mathrm{mg}$, $10.7 \mu \mathrm{mol}, 1.00$ equiv) was dissolved in ${ }^{i} \mathrm{PrOH}\left(0.4 \mathrm{~mL}\right.$, distilled over $\mathrm{CaH}_{2}$ and stored over $4 \AA$ molecular sieves) in a Young NMR tube under argon. A $0.33 \mathrm{M}$ solution of $\mathrm{Na}{ }^{i} \mathrm{PrO}$ in ${ }^{i} \mathrm{PrOH}$ (32.0 $\mu \mathrm{L}, 10.7 \mu \mathrm{mol}, 1.00$ equiv) was added, followed by $0.1 \mathrm{~mL}$ of $\mathrm{C}_{6} \mathrm{D}_{6}$ as lock. The ${ }^{31} \mathrm{P}\left\{{ }^{1} \mathrm{H}\right\} \mathrm{NMR}$ spectra of the reaction solutions (Figures S16-18) showed quantitative conversion of 4 to $\left[\mathrm{Fe}\left(\mathrm{O}^{\prime} \mathrm{Pr}\right)\left(\mathrm{CNCEt}_{3}\right)(\mathbf{1})\right]\left(\mathrm{BF}_{4}\right)(8)(65 \%)$ and $\left[\mathrm{FeH}\left(\mathrm{CNCEt}_{3}\right)(\mathbf{1})\right]\left(\mathrm{BF}_{4}\right)(3)(24 \%)$ and to some $\left[\mathrm{Fe}\left(\mathrm{CNCEt}_{3}\right)_{2}(\mathbf{1})\right]\left(\mathrm{BF}_{4}\right)_{2}(2)(11 \%)$ as decomposition product (Table S8). Heating to $50{ }^{\circ} \mathrm{C}$ increased the concentration of hydride $3(70 \%)$ at the expense of the 2-propoxo complex 8 (24\%), whereas the amount of the decomposition product (2) remained almost unaltered (6\%) (Figure S16, Table S8, entry 2). Data in gray in parentheses refer to the reaction carried out in 2-propanol distilled over $\mathrm{CaH}_{2}$ without treatment with molecular sieves. 
Table S8. Species distribution in the reaction of $\left[\mathrm{FeBr}\left(\mathrm{CNCEt}_{3}\right)(\mathbf{1})\right] \mathrm{BF}_{4}$ with $\mathrm{NaO}^{\prime} \operatorname{Pr}(1$ equiv) in 2-propanol stored over molecular sieves.

$\begin{array}{ccccc}\text { entry } & T\left({ }^{\circ} \mathrm{C}\right) & \mathbf{8}(\%) & \mathbf{3}(\%) & \mathbf{2}(\%) \\ 1 & 25 & 65(80) & 24(10) & 11(10) \\ 2 & 50 & 24(62) & 70(29) & 6(9) \\ 3 & 25 & 54(81) & 36(9) & 10(10)\end{array}$

Figure S15. ${ }^{31} \mathrm{P}\left\{{ }^{1} \mathrm{H}\right\}$ NMR spectrum (202 MHz, $\mathrm{C}_{6} \mathrm{D}_{6}$ lock) of the reaction of 7 with $\mathrm{NaO}^{\prime} \mathrm{Pr}$ (1 equiv) in ${ }^{\mathrm{i}} \mathrm{PrOH}$ at $298 \mathrm{~K}$ (traces of $\left[\mathrm{Fe}(\mathrm{ACN})_{2}(\mathbf{1})\right]\left(\mathrm{BF}_{4}\right)_{2}$ were present as impurity in the starting material).

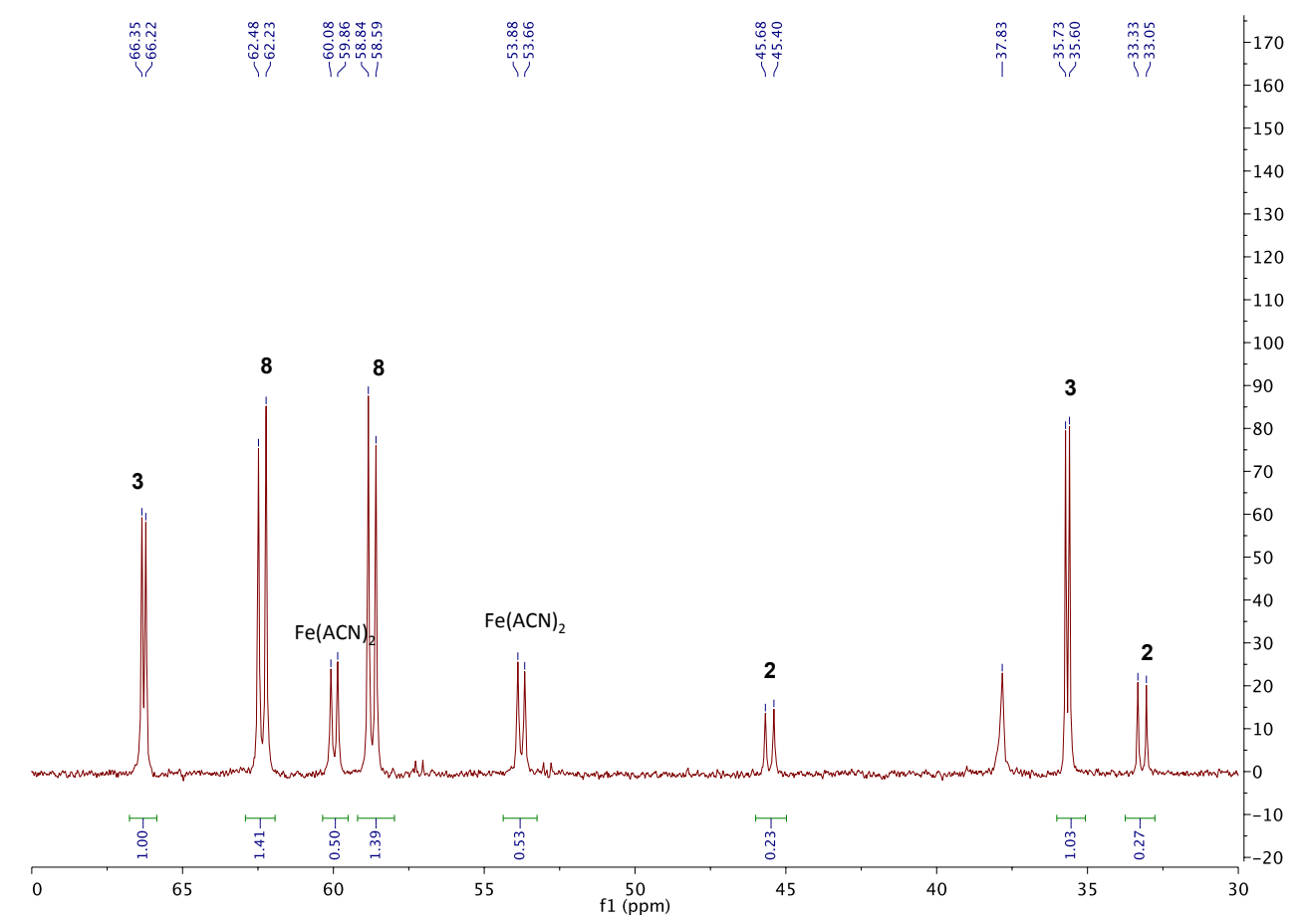


Figure S16. ${ }^{31} \mathrm{P}\left\{{ }^{1} \mathrm{H}\right\}$ NMR spectrum (202 $\mathrm{MHz}, \mathrm{C}_{6} \mathrm{D}_{6}$ lock) of the reaction solution containing 7 and $\mathrm{NaO}^{\prime} \mathrm{Pr}$ (1 equiv) in ${ }^{i} \mathrm{PrOH}$ at $323 \mathrm{~K}$ (traces of $\left[\mathrm{Fe}(\mathrm{ACN})_{2}(\mathbf{1})\right]\left(\mathrm{BF}_{4}\right)_{2}$ were present as impurity in the starting material).

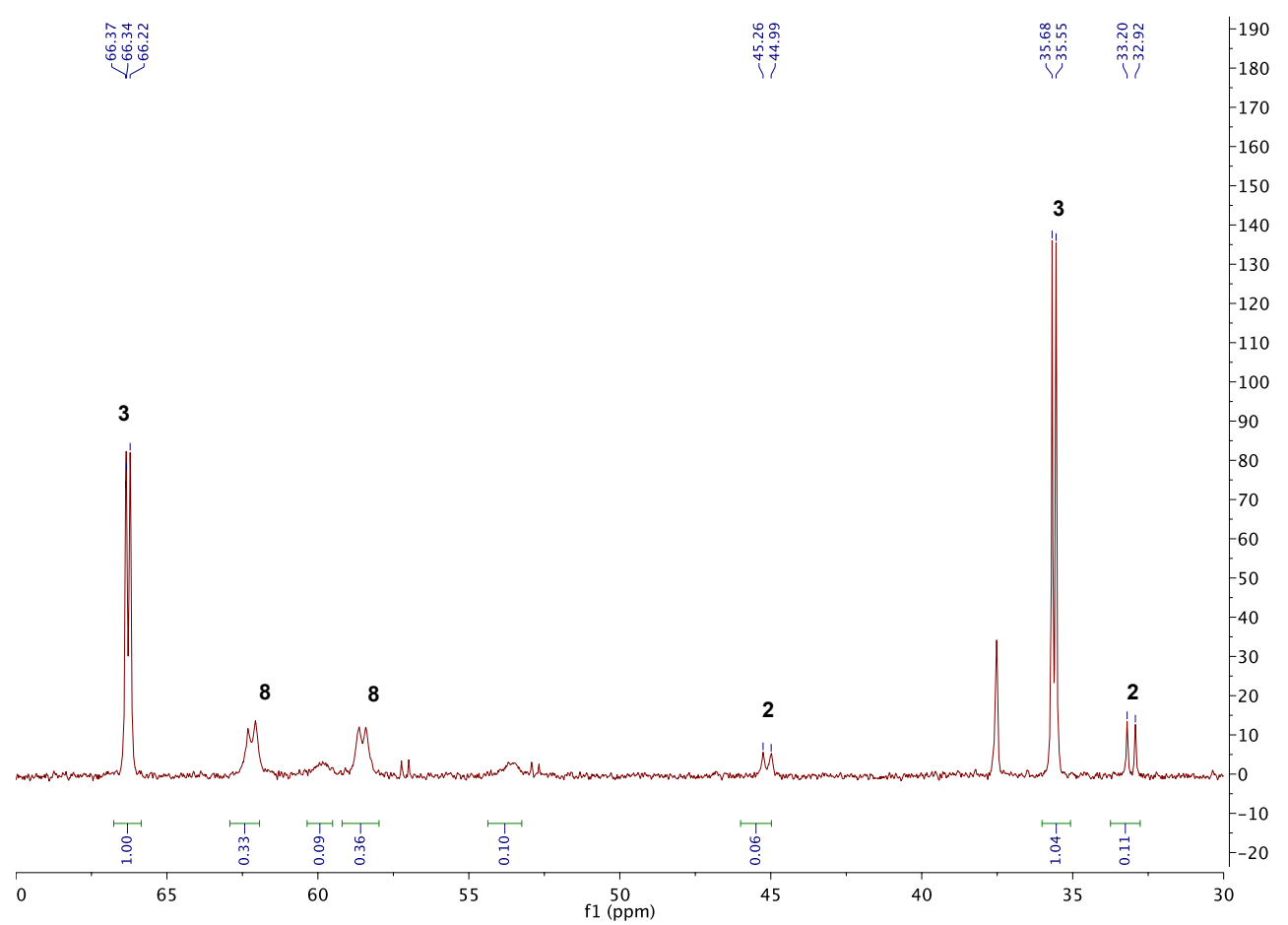

Figure S17. ${ }^{31} \mathrm{P}\left\{{ }^{1} \mathrm{H}\right\}$ NMR spectrum (202 MHz, $\mathrm{C}_{6} \mathrm{D}_{6}$ lock) of the reaction solution containing 7 and $\mathrm{NaO}^{i} \mathrm{Pr}$ (1 equiv) in ${ }^{i} \mathrm{PrOH}$ at $298 \mathrm{~K}$, after heating (traces of $\left[\mathrm{Fe}(\mathrm{ACN})_{2}(\mathbf{1})\right]\left(\mathrm{BF}_{4}\right)_{2}$ were present as impurity in the starting material).

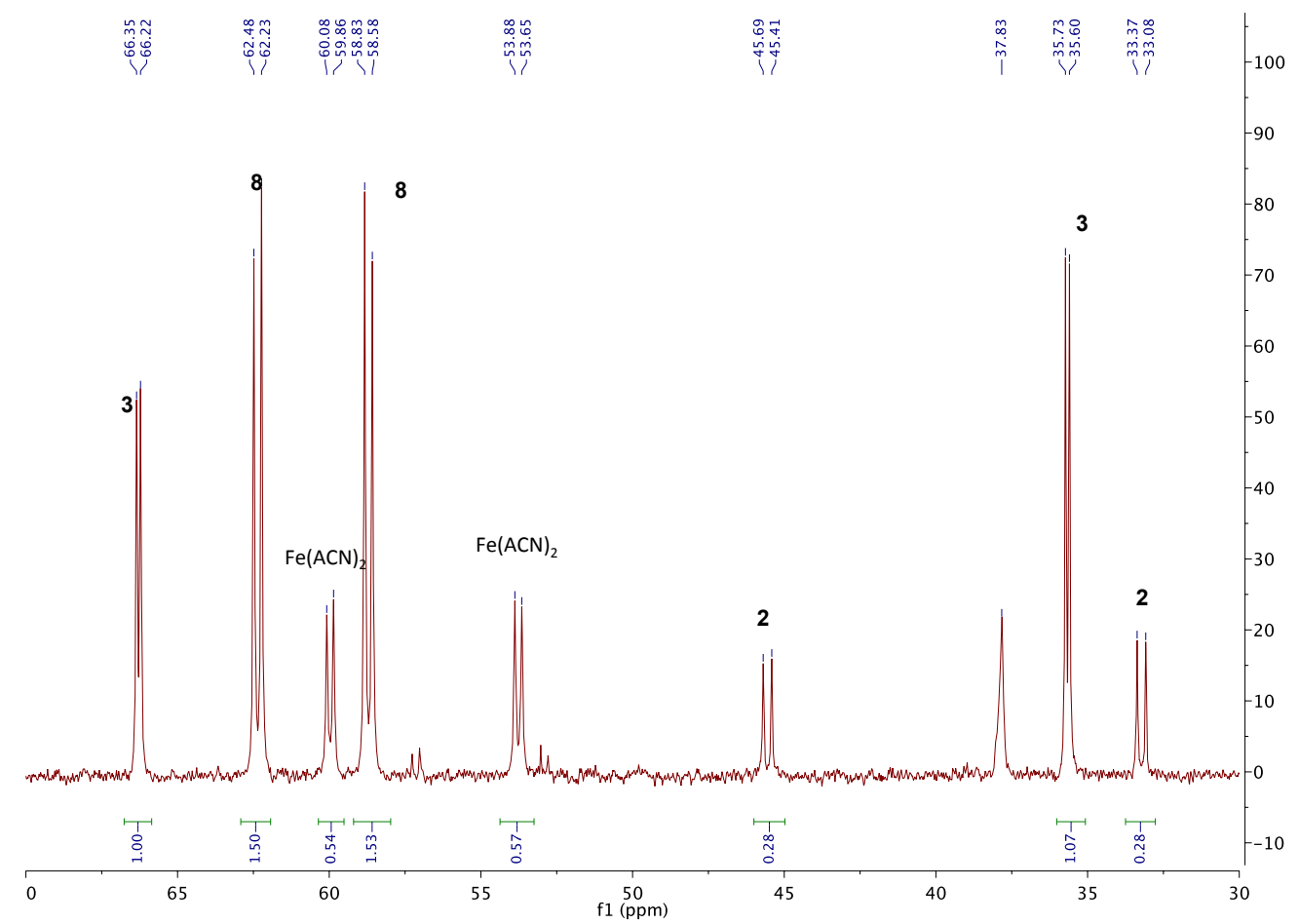




\section{References}

(1) De Luca, L.; Passera, A.; Mezzetti, A. Asymmetric Transfer Hydrogenation with a Bifunctional Iron(II) Hydride: Experiment Meets Computation. J. Am. Chem. Soc. 2019, 141 (6), 2545-2556. https://doi.org/10.1021/jacs.8b12506. 